\title{
Research on the risks of RMB internationalization and strategic planning
}

\author{
QianHong Li
}

Harbin Engineering University, Finance Science, Harbin, China, 150000

Keywords: RMB,Internationalization,Economy,Risk,Planning

\begin{abstract}
The RMB internationalization has been paid more attention by the people since the "American subprime mortgage crisis" Occurred in 2008, which can not only increase the financial risks in our country but also weaken the independence of the monetary policy in our country. However, RMB internationalization can bring new power for the economic development in our country, the paper analyzes the main risks brought from RMB internationalization and puts forward the strategic planning on RMB internationalization combined with the national situation in our country.
\end{abstract}

\section{Introduction}

In the 21st century, the dollars continued to depreciate, though China achieved the high increasing in export and economy, its accumulated massive reserve of dollar assets encountered with large losses in purchasing power, the dollars have depreciated by 75.6\%[1]aiming at 16 types of bulk commodities since the 21st century. In order to prevent the developing countries in Asia accumulating massive dollar reserves from being damaged under the crisis, it is needed to maintain the interests of the weak countries through the restraints of international communities on the fluctuation of international exchange rate. And China maybe escape from this passive situation through RMB internationalization.

After the global financial crisis erupted in 2008, the Chinese government established the basic policy of RMB internationalization, and began to promote the pilot projects of RMB cross-border trade settlement from 2009, however, the "cyllopodia" Phenomena of $80 \%$ import settlement generated after 3 years of pilot project promotion of RMB cross-border trade settlement, which went contrary to the wishes and caused more foreign currency reserve and greater exchange rate risk. In addition, the capital cross-border flow caused by the interest arbitrage activities between the inland and Hong Kong worried the scholars, the deputy governor of the World Bank and the chief economist Lin Yifu (2012) put forward that the conditions of RMB internationalization were not mature, thus it can be seen that the RMB internationalization process must rely on the summary on the growth experience of international reserve currency as well as specifying the dominant situation and basic situation of currency internationalization thus to make effective promotion strategy.

\section{Risks}

Massive flowing- in and flowing-out risks of capital. The RMB internationalization certainly will speed up the liberalization process of capital account, afterwards, the capital flow at home and abroad will be more convenient, the massive flowing-in of capital will increase the exterior liabilities of our country, once the balanced mechanism of internal and external market changes, massive capital transferring will generate,which will no doubt cause great impact on the safe operation of our economy and finance and aggravate the economic recession of our country.

(1) Massive flowing-in risk of capital

In accordance with the explanation on the evolution of financial crisis by kindleberger(1978), combined with the actual situation of China, the capital flowed in largely after the RMB internationalization and finally resulted in the evolution of financial crisis, which consisted of three stages:

Stage 1: RMB could be freely exchanged after its internationalization, which made capital flowing-in more free, once the domestic interest rate was higher than the international interest rate, 
the capital would flow in largely, moreover, the Central Bank recycled the domestic currency through releasing RMB Bonds to the world thus to produce more fluidity in domestic; therefore, the impact of external capital flowing-in on macro economy was strengthened.

Stage 2: the constant flowing-in of capital caused the economic activity reached to its peak, the price of assets rapidly increased, the financial institutions such as banks largely released loans, meanwhile, the enterprises were excessively in debt, the virtual economy developed rapidly in short period and gradually deviated from the internal value of real economy, the capital investment achieved high returns in short time and almost everyone left the risks after the bursting of asset bubble behind.

Stage 3: with the rapid development of asset bubble, the increasing demands on capital tended to speed up the currency circulation, and then the interest rate began to rise[2], the asset liabilities of the enterprises further enlarged, the investors were difficult in repaying and they cashed out through selling the financial assets, therefore, the asset price sharply reduced, large quantity of capitals began to withdraw, the asset bubble burst, the financial institutions such as banks went bankrupt and finally the financial crisis came.

(2) Abscondence risk of massive capitals

Abscondence of massive capitals would result in the huge deficit of capital project and finally cause the unbalance of international revenue and expenditure, besides, it would cause the instability in the value of RMB, the trend of RMB internationalization tended to ask for the free fluctuation of exchange rate of RMB, while the frequent flow of international capital would certainly strengthen the fluctuation of exchange rate of RMB, furthermore, abscondence of massive capitals would weaken the effect of macro economy policy made by the monetary authority to some extent. Finally, it would also enlarge the wealth gap in domestic and result in social instability.

Risk of difficulty in regulating the monetary policy.besides, managing and controlling the capital flow is also the current choice for China, RMB needs to go out, the two features such as free floating of RMB exchange rate and free flow at home and abroad of capital determine that China should change the current road.

Under the situation of open economy, the internal and external equilibrium is the goal of macroeconomic policy. When the real economy deviated from the internal and external equilibrium, the currency authority must conduct adjustment by applying economic policies. Meada (1951) analyzed the internal and external equilibrium under the situation of open economy in the book of International Revenue and Expenditure and put forward "Meada conflict". he thought the government could not apply the exchange rate policy under the fixed exchange rate system, therefore, in the process of relying on the single expenditure increasing and decreasing policy to seek for the internal and external equilibrium, the problem that the internal equilibrium and external equilibrium would conflict with each other maybe exist. In accordance with the Mundell-Fleming model, under the economic opening system of free capital flow, if adopt fixed exchange rate system, the monetary policy will be invalid, while under the floating exchange rate system, the monetary policy will be valid; the "impossible trinity" put froward by Mondale, namely the triangle formed by monetary policy independence, fixed exchange rate system and free capital flow, wherein, only two of them for the currency authority to choose in the policy combination, namely persisting in capital management to implement fixed exchange rate or untightening the capital flow to implement floating exchange rate. After the Bretton Woods System broke up,the developed countries in western countries were more easier to choose monetary policy independence and floating exchange rate system for capital flow,while the developing countries were more easier to choose monetary policy independence and stable exchange rate owing to the difficulty in undertaking the unstable exchange rate and abscondence of massive capitals resulting from currency devaluation, Impacted by the dollars, the floating exchange rate system in our country has not escaped from the limitation of fixed exchange rate system at present, therefore, the internationalization for RMB will certainly transform from the fixed exchange rate to completely free floating exchange rate, however, in this process, the effect of monetary policy will be discounted owing to RMB internationalization.

Risk of currency substitution. Currency substitution refers to under the situation of open 
economy and exchangeable currency, the domestic currency depreciation or other factors cause the domestic residents lose confidence in domestic currency thus result in the phenomena that partial or all functions of the domestic currency are substituted by foreign currency, thus it can be seen that RMB internationalization provide possibility for currency substitution on RMB. Currency substitution not only can disturb the normal financial order in our country and weaken the control right of Central Bank on financial system but also can hinder the independence of monetary policy and impact the effect of monetary policy on macro economy. (Liu Lizhen, Xu Qiyuan, 2006)

Triffin dilemma."Triffin dilemma” refers to: the value of dollar can not be taken as the international currency if it tend to be stable, the value of dollar is difficult to be stable if it tend to be the international currency. Currency internationalization not only makes the country issuing currency enjoy the proud position and obtain the royalty but also forges the country to pay the costs and even take long-term economic recession and financial depression as a cost, in fact, any countries with the currency internationalization will face with "Triffin dilemma", under the situation of RMB internationalization, China is bound to step on the road of changing for universal currency with balance of payment deficit, and it is still a topic needing to be discussed for whether China can bear the risks from "Triffin dilemma” under the situation of RMB internationalization.

\section{Strategic planning}

Step towards the internationalization from exchange rate reform. The first step for RMB internationalization can only start from exchange rate reform, any country wants to obtain the autonomous right in the exchange rate problems, which is the instinct for a country. Since China can not firmly observe the old system, it must conform to the times and choose a new system which can maximally guarantee the national interest. It is proved from the experience and lessons of the previous countries that the key problem needing to be solved for a country transforming the exchange rate is how to stably exit from the old system and smoothly transfer to a new system, from the perspective of the routes of system evolution, the simple dichotomy of the reform of gradual model and radical model is popular in the transition economics. Radical model refers to settle a matter in one step, while gradual model refers to establishing buffer period for system reform and making transition arrangement. Currently, we can make the optical choice: adopt the floating exchange rate under management and under the multivariate standard system, which is gradual and progressive. On the one hand, gradually broaden the range of floating to form the RMB exchange rate more flexible [3]; on the other hand, gradually eliminate the close connection with dollar, realize the joint floating with various international currencies and then make choices thus to make RMB exchange rate system more flexible.

Promote to form "regional hard-currency". With the enhancement of the international position of our country, the economic trades and transactions in surrounding countries or regions adopt RMB to calculate the price, settle and pay, which in fact is the preliminary format of RMB internationalization. In 1994, RMB realized the conditional conversion for frequent projects, in December of 1996, RMB realized the free conversion for frequent projects, which marked RMB took a key step in internationalization; in the border trades and overseas tourism service activities, RMB has become the "welcomed currency" with influence and chosen the mode of Yen internationalization as the route in its internationalization, which conforms to the national situation of China. In the increasingly fierce international community, RMB can realize the internationalization by relying on the improvement of comprehensive national strength and enhancement of international position thus to come close to the goal of international hard currency and win in the competition.

Promote the birth of Asian currency. When RMB exists simultaneously with Yen, in order to prevent the increase in the opportunity cost for the development of Japan and China, the two countries should negotiate with each other as early as possible, jump from the interest view, clearly know the advantages and disadvantages respectively in cooperation and competition from the objective perspective, put the political disagreements aside, release the monetary power and then negotiate with Korea, Hong Kong and Taiwan to promote the birth of Asian currency and unify the 
Asian currency, which will be beneficial for the financial and economic development of Asia and the world as well as helpful for China: (1) Hopeful to end the history of four currencies in one country thoroughly (2) Make China positive and active in leading the process of Asian currency; (3)Make China establish the new economic system based on its own international currency;(4) Obtain large coin taxation. If all the above items can be realized, related experts predict that the GDP of China will double or quadruple.

Encourage the Chinese industries and financial capital to take root in overseas and establish the "network externality" of RMB. From the perspective of national strategy, the core interest of RMB internationalization lies in the price calculation function of RMB in international commodities and financial trades thus to help China escape from the international exchange rate risk. However, the price calculation function of RMB relies on going-out and dominant right obtaining in international trade,investment, production and financial activities of Chinese enterprises and financial institutions thus to form the "network externality" of RMB in international trade and financial trades. Otherwise, the RMB assets held by the foreign investors for the appreciation expectation will cause the expansion of asset bubble in China, once the foreign investors withdraw the capital, the financial crisis will occur, which will result in the reversion of RMB internationalization process. The American expert Subramarian(2011) from Peterson Institute for International Economics put forward in the book Predictions that international currency is a "double-edged sword" for the countries issuing the currency: the excessive development and usage of America on dollar privileges has made the industrial structure distorted and the employment positions decreasing, in addition, the reliance on exterior has increased and the fluctuation in economy has enlarged,which result in the hazards similar to "Dutch disease". Therefore, currency internationalization should be placed in a proper space, otherwise, it will do harm to the internal economy. In order to develop proper RMB internationalization, it should be orientated in Asian regionalization, namely, expand the usage of RMB mainly in Asia, promote the industrial capital and financial capital of China to develop in Asia and other regions, transfer from trade settlement to capital output thus to make RMB take root in the real economies centering on Asia, play its price calculation function better and gradually form the "network externality" of RMB internationally.

Promote the transformation of economic development mode and reform of financial system to maintain the sustainable growth of China's economy. The sustainable growth of China's economy is the most important determinant for RMB internationalization, while the transformation of China's economic mode is the requirement to realize the sustainable growth of China's economy; with the decline in relative positions of America and Europe and the fiscal contraction, the consumption in America and Europe supporting the export of China has never had sustainability , the power for the demands of sustainable growth can be guaranteed under the situation of the transformation of China's economy from export-oriented type to domestic-demand-driven type, meanwhile, the traditional growth mode of high input and low-profit has faced with severe resource environment restriction, only through reforming the economic system and promoting the production efficiency can the power be provided for the sustainable economy growth. Only through domestic demand driving and improving the transformation of efficiency can China's economic mode support the long-term confidence of the international investors in China's economic growth thus to create a sustainable and stable international demand for RMB. The marketization reform of financial system is the capital market of China's sustainable economy which has two features of strict limitation on market entry and actual negative interest rate of deposit.

The important defect of this financial system is the long-term impairment on the interest of middle class which is the necessary precondition in developing the internal demand market and developing the service industry in the economic transition of China as well as the power source for the demand of sustainable growth in China's economy. In addition, the financial system of administrative-monopoly type has become the restrictive bottleneck in the transformation from household savings to new-type high-growth industrial investment, however, the high-tech industry and service industry are the new power for sustainable economic growth,therefore, it is needed to rely on the financial system reform to guarantee the constant fund support. 


\section{References}

[1] Y.L.Pan.The Path of RMB Internationalization and Its Significance to Shanghai[J]. Scientific Development, 2012, 6(1): 18-21.

[2] H.Q. He. The Risk of RMB Internationalization and Its Prevention[J]. Journal of Yan'an University, 2012,6(1): 79-82.

[3] F.Zhang. Promoting the Reform of RMB Exchange Rate RegimeSteadily[J]. Western Finance, 2011, 3(1): 66-67. 